\title{
Life satisfaction among inbound university students in northern Sweden
}

\author{
PER A. NILSSON \& BRITT-MARIE STÅLNACKE
}

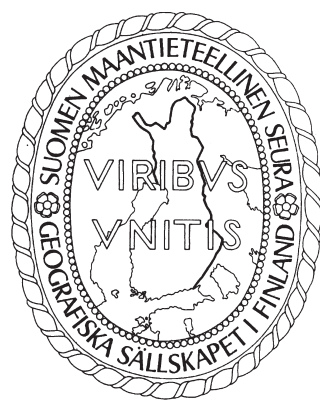

Nilsson, P. A. \& Stålnacke, B. M. (2019) Life satisfaction among inbound university students in northern Sweden. Fennia 197(1) 94-107. https://doi. org/10.11143/fennia.70337

$\mathbf{y}$ Will life satisfaction among international students change after having an experience of studying abroad? Some previous studies indicate inequalities and issues of social mobility embedded in international student mobility. International student mobility implies physical movement and new experiences gained while studying abroad. The ubiquity of international students and their generally successful adaptation makes it necessary to understand how they manage to turn a seemingly difficult situation into satisfying adaptation. One area of such concern that this study sought to explore was the students' level of satisfaction with life. This study investigated the self-reported life satisfaction of inbound university students upon arrival to a university in northern Sweden and at follow-up six months later. After the study period abroad, the students' levels of perceived satisfaction with their somatic health and activities of daily living had significantly increased. Higher levels, while non-significant, were found for the domains life as a whole, study situation and economy. These findings may indicate that studying abroad could have an impact on students' reported life satisfaction, which highlights the value of a period of studying abroad. However, when exploring life satisfaction outcomes among internationally mobile students, it seems pertinent to study student mobility within a context. This study mostly targets international student mobility in a Western/ European context.

Keywords: inbound students, student mobility, life satisfaction, Sweden

Per A. Nilsson, Department of Geography, Umeå University, 90187 Umeå, Sweden.E-mail: per.a.nilsson@umu.se

B. M. Stålnacke, Department of Community Medicine and Rehabilitation, Umeå University, 90187 Umeå, Sweden.E-mail: britt-marie.stalnacke@umu.se

\section{Introduction}

As the number of international students increases globally (OECD 2014), the need to understand and address these students' cultural and psychological adjustment to a new country becomes increasingly important. The experience of studying abroad involves adapting to a new culture and new surroundings, where the culture, religion, language and social life often differ from those of the student's home country (cf. Lin \& Yin 1997; Rode et al. 2005; Russell et al. 2010; Rienties \& Tempelaar 2013). The degree to which the students adapt to new settings will have an impact on how satisfied they are with their life as an international student. Life satisfaction, described as an overall cognitive and judgmental assessment of personal quality of life according to self-selected criteria (Shin \& Johnson 1978; Pavot 
et al. 1991), has been used as a social indicator of the meaningfulness of life (Melin 2003). Life satisfaction concerns the individual's contentment with life, and whether his or her aspirations and achievements have been accomplished (Jacobsson \& Lexell 2013). In evaluations of students' contentment with life after a sojourn abroad, their reports on life satisfaction can be useful for exploring different dimensions of mobility, and lifestyle-led mobility can be an expression of social differentiation and inequality (Urry 2000, 2002; Murphy-Lejeune 2002).

International student mobility implies both spatial and upward social mobility, indicating inequalities embedded in student mobility favouring those who have the means and resources to study abroad. Some previous studies have turned to studying social differences within the globalizing higher education system (cf. Findlay et al. 2012; Bilecen \& van Mol 2017; Börjesson 2017). Other researchers view this as an expression of new mobilities, emphasizing a search for a better life somewhere else, which is a defining characteristic of contemporary life (Cresswell 2006; Sheller \& Urry 2006). In relation to non-mobile students internationally, mobile students have been found to be a selected group of students (Waibel et al. 2017). Students have different individual expectations before becoming international students, which colour their experiences after having studied in a foreign country (Benson \& O'Reilly 2009) and may affect their satisfaction with life. However, in most previous studies of international student mobility, the students have only been surveyed on one occasion (e.g. Paige et al. 2009); few studies have captured a study-abroad experience via both pre- and post-surveys (Kennedy 2010). To our knowledge, there is also a lack of studies of life satisfaction in relation to international student mobility. Therefore, this article aims to answer the following question: Will life satisfaction among international students change after having an experience of studying abroad?

Studies of life satisfaction among internationally mobile students can add knowledge to procedural perspectives on mobility practices and move away from a static perception of international student mobility (Lysgård \& Rye 2017). For the purpose of this article, international student mobility implies temporary movement (King et al. 2010); the term is used with the interpretation that the students relocate to other places temporarily, implying at least an ambition to return to the place of departure.

\section{Temporary movement of international students}

Geographers have become more interested in international student mobility (e.g. Brooks \& Waters 2010; Deakin 2014; Prazeres 2018), mainly focusing on the relationship between education and mobility. For example, Perkins and Neumayer (2014) explore the uneven flows of international students and Beech (2014) the role of social networks. The discipline itself has witnessed a large increase in studies on various aspects of mobility, for instance the awareness of the interplay between mobility and migration within the context of contemporary globalization, transnationalism, and mobility (Hall \& Page 2009). Hall, Williams and Lew (2014) emphasize dimensions of temporary mobility and circulation, the multidisciplinary realm of mobility studies, and the integration of disciplinary perspectives. For geographers' studies of mobility have been essential for decades; not only physical movements but also interaction when it comes to communication and exchange of information have been addressed, for example virtual mobility, a shift in mobility as a convergence of physical travel and communications (Bell \& Ward 2000; Janelle \& Hodge 2000; Urry 2000, 2002).

As a concept mobility has shown to be complex and multifaceted, and together with other disciplines a 'new mobilities paradigm' (cf. Cresswell 2006; Sheller \& Urry 2006) has been developed, turning away from a static way of viewing mobility to emphasizing that in contemporary life it has become an important dimension and something that continues throughout the life course. It is obvious that movements of people are embedded in the complexity of their everyday lives and experiences. Bogren (2008) argues that it is a challenge to draw a line between mobility and migration due to how mobility and circulation are conceptualized in contemporary society, characterized by repeated moves, even though some have labelled time-limited migration across national borders 'temporary migration' (Boyle et al. 1998).

Many scholars have pointed out that living abroad can last anywhere from a short period, such as being a tourist, to a long duration (Åkerlund 2017), and the discussion has circled around the accuracy of using migration and/or mobility. The discussion has concerned distance, boundaries and duration 
in regard to movements (Boyle et al. 1998). Some researchers have studied temporary migration such as seasonal migrants, commuter migrants, tourists, and degree-seeking students (cf. King \& RuizGelices 2003). Meanwhile, others have studied long-term migration, for instance workers seeking permanent employment elsewhere, business migrants who establish a business in the receiving country, or forced migration due to political or religious reasons (Boyle et al. 1998). When reflecting on the international experience of living in a foreign country among students, the migration/mobility division is complex. It is evident that international student mobility is blurred in regard to the concepts of migration and mobility, for instance exchange students who study abroad but return to their home university to finish their studies and receive a degree. For many students, such as Erasmus students, international mobility is about temporarily studying abroad. The Erasmus programme, financed by the European Union, enables students to study and train abroad for a period of at least three months for studies and for a two-months period for an internship (European Commission 2014).

Thus, the time frame for an international experience differs; Knight (2012) has explored different categories of student mobility and what is included in the concept. Students can be restricted to studying at the university and/or country where they are admitted, or to agreements between the home university and a foreign higher education institution ( $\mathrm{HEI})$. Some students do not have much of a choice while others can choose freely; but for most students, at least in the Western world, studying abroad is an available option. International student mobility implies a high probability of returning for those participating in credit mobility (exchange students) with a short duration. A degree student is a student who participates in an entire programme to complete an education; for these students, especially from developing countries, this implies a long or even permanent residence abroad (King et al. 2010).

In our society, distant places are brought closer together due to the decreased travel time between locations. This is often labelled space-time compression (Hall 2005a, 2005b). For those with sufficient time and money, mobility has become easier. Time-space convergence suggests that accessibility between some places increases as technologies enable more rapid communications, and regards it as a multiple process rather than a one-way ticket (Murphy-Lejeune 2002). Moreover, student mobility also includes aspects of social mobility motivating students from different socio-economic backgrounds whose careers will benefit from studies abroad (Findlay et al. 2006). A person's move can indicate upward social mobility, for instance a move from an economically less advanced to an economically more advanced country where a $\mathrm{HEl}$ is viewed as superior in academic quality. Teichler (2017) refers to this as vertical mobility. Consequently, horizontal mobility refers to a move to a HEl of equal quality, which would be true for many of the students enrolled in exchange student programmes such as the Erasmus programme. The study destination is more or less on equal terms with the home $\mathrm{HEl}$ and the country of origin. This indicates that mobile students do not expect a higher level of teaching or substance of knowledge being taught.

\section{Students' backgrounds and inequalities}

Students often have a blend of motives for choosing to study abroad, and mobility can be a way of achieving their lifestyle aspirations and contentment with life. While there are many positive individual motives for studying abroad, such as personal development, finding a job after graduation and academic challenge, some scholars have discussed the obstacles embedded in student mobility (Souto-Otero et al. 2013). In a Western/European context, these obstacles can involve aspects such as the student's social background or academic confidence (Ibid.; UKÄ 2016). Previous research has shown that studying abroad is highly dependent on students' background characteristics. Students from academic families are more liable to go abroad than those from non-academic families (cf. Hauschildt et al. 2015), and are therefore more likely to gain the benefits of studying abroad. Having access to HEls in other countries will also form the individual's career trajectory. Studying abroad implies not only access to formal knowledge but also, and perhaps more importantly, social and cultural knowledge. Thus, international spatial mobility is often considered to be a way to achieve upward social mobility, and it is essential to scrutinize the relationship between spatial mobility and social mobility. 
It has been shown that English-speaking countries attract internationally mobile students, but that students from English-speaking countries are travelling to a lesser degree to other countries for studies (UNESCO 2014). For UK students, the place of study is pertinent for their further life planning. In a study by Findlay and colleagues (2012), outbound students from the UK were concentrated in a few countries with prestigious HEls. The study concluded that different dimensions of social and cultural capital are accumulated through studying abroad, and, furthermore, that study abroad can be viewed in the light of students' wider life course aspirations and not only as a way of receiving a formal education; it is more about being part of a wider process including socially and culturally constructed knowledge, producing a global hierarchy of HEls (Ibid.). For studying the intersection with social mobility, Findlay and colleagues (2012) have suggested that place studies of international mobility within a context - such as Western/European and/or mobility from developing countries are best for scrutinizing new patterns of inequalities and differences embedded in international student mobility.

The costs for developing countries when university students move to better opportunities at HEls and businesses in the developed world is another expression of the inequality and differentiation embedded in international student mobility (Bhagwati 1976). Some scholars have used the term brain circulation to emphasize the transfer of knowledge included in the process of student mobility when students move to a foreign country, integrating in the destination country and at the same time maintaining contact with the home country (Olutayo 2017). It is evident that many students are in search of better opportunities, such as higher salaries, standard of living, and quality of life. However, some will return home or maintain their links to the home country, generating brain gain and circulation; according to Welss (2014), there is no credible evidence that internationally mobile students contribute to brain drain.

In Sweden, international student mobility is judged to be an asset in a global knowledge-based economy and to be beneficial to students as well as the country (SOU 2018, 3). Even though mobility is encouraged in a Swedish context, it seems that in practice the choice is not available for most students. Börjesson (2005) concluded that the 'social elite' has the most to gain from an internationalization of higher education. Studies have shown that students' socio-economic background will influence their possibilities to study abroad, indicating issues of inequality and difference in Swedish student mobility (cf. UKÄ 2016).

\section{Life satisfaction among international students}

Mobility can be a way to achieve one's lifestyle aspirations and greater life satisfaction. Life satisfaction has been used as an overall social indicator of the meaningfulness of life (Fugl-Meyer et al. 2002), and has been defined as a person's overall evaluation of his or her life (Shin \& Johnson 1978; Pavot et al. 1991). Life satisfaction represents an individual's contentment with his or her life, and the degree of the individual's subjective appraisal as to whether his or her aspirations and achievements have been accomplished (Jacobsson \& Lexell 2013). In studies comparing life satisfaction between nations it has been shown that living conditions exert a strong influence over average life satisfaction with a higher average life satisfaction in economically wealthy countries than poorer nations (Helliwell et al. 2017). Concerning the variance in life satisfaction between nations, it has been shown that more highly educated countries experience higher levels of satisfaction. However, from the perspective of individuals the effect of education on life satisfaction is stronger when few people within a country have gained a high level of education. This means that a person with an academic degree in a country with low average education probably experiences a higher life satisfaction than a person with an academic degree in a more highly educated country (Salinas-Jiménez \& Salinas- Jiménez 2011).

Some studies have examined life satisfaction among students and found that this concept seems to be of importance as an indication of how well students adjust to the new situation of studying abroad (Salimi 2011; Yalçun 2011). According to Chow (2005), age, stress, physical health, style of studying, parenting style, lifestyle, and personality constructs are major determinants of life satisfaction among populations of university students. In addition, studies have observed the extent of loneliness and/or isolation among international students (cf. Sandhu 1994; Sawir et al. 2008; Russell et al. 2010). 
Exposure to an unfamiliar environment can create anxiety, confusion and depression, leading to experiences of insomnia and physical illness, all of which can interfere with a student's studies, friendships, and social life (Lin \& Yin 1997). Moreover, financial concerns and being away from home have been identified as common stressors among international university students (Bhandari 2012).

In a study by Sam (2001) on life satisfaction among a group of international students in Norway, it was found that on the whole the students reported good satisfaction with life. However, students from Europe and North America were generally more satisfied than their peers from Africa and Asia (Ibid.). Economic situation, social networking, and perceived discrimination are factors that have significance for life satisfaction (Shin \& Johnson 1978; Pavot et al. 1991; Rode et al. 2005; Russell 2010; Rienties \& Tempelaar 2013). Even though some previous research has shown that studying in a foreign country can be demanding because of the need to adjust to a new culture, studies have also shown that students participating in student mobility, especially exchange students, report a desire to travel, to experience another culture, and to enhance their language skills as reasons for wanting to study abroad (cf. Teichler 2002; Bracht et al. 2006).

Accordingly, studies on life satisfaction have shown differences between students of different origins, for instance between Western/European countries and developing countries (Sandhu 1994; Sawir et al. 2008; Kondakci 2011). These studies mostly report 'negative' experiences for students from outside Western/European countries such as demanding studies, having to deal with life in a new culture, stress, and loneliness. International students face both shared and unique problems, and this can be explained partly by different objectives for studying abroad and the place the students originally come from (Sandhu 1994; Sawir et al. 2008). The purpose of studying abroad can also differ between degree and credit students, with regard to life course aspirations such as starting an international career (Bracht et al. 2006; Varghese 2008; Wiers-Jenssen 2008).

There are also driving and restraining forces embedded in life satisfaction. Drivers for studying abroad can emerge closer to students' home countries with a cultural familiarity, or far away where the cultural differences are huge (e.g. Burns 1991; Sandhu 1994; Sawir et al. 2008; Russel et al. 2010; Bhandari 2012). Studying abroad can be a chance to leave the country for other lifestyle opportunities than what is possible at home. This can also entail a great effort for students to participate in the globalized world with its many competitions and constraints. This can lead to a reduction in perceived life satisfaction when place attachment and social relations are decreased, such as separation from families and friends, and mental health problems (cf. Sandhu 1994; Sawir et al. 2008; Russel et al. 2010; Forbes-Mewett \& Sawyer 2016). Still, some studies indicate that students engage in 'life planning' embedded in their future life course aspirations, with mobility offering a way to achieve these objectives (Findlay et al. 2012).

\section{Studying student mobility with the Life Satisfaction Questionnaire}

\section{Procedure}

Umeå University is a comprehensive university in northern Sweden, with approximately 33,000 students at the time of the investigation. An important profile of Umeå University is sports, exercise, and outdoor activities. The proportion of inbound students as a share of the total student population is approximately $7 \%$. Umeå University can offer international students service and social support. A Buddy Programme is specially designed to offer students from the host country the chance to connect with international students and to share their culture and help them integrate with the rest of the student community.

The data used here were collected through surveys directed at inbound students at Umeå University. These students were recruited from the group of who had enrolled before the beginning of the 2008 autumn term. All inbound international students who attended an introduction day, 400 individuals, received the survey upon arrival, and 296 students ultimately responded. After six months of studying abroad, the responders were invited to a follow-up. The panel consisted of 116 respondents, that is students who had answered the survey upon arrival and after six months of studying abroad. 
The arrival survey yielded a response rate of $74 \%$ and the follow-up survey $40 \%$. The characteristics of the panel are shown in Table 1.

The analyses are based on the follow-up data from the survey monitoring the students' life satisfaction while studying abroad. Reported life satisfaction was measured before and after their period of studying abroad, which was approximately six months. The strength of this study is its focus on a follow-up of international students' life satisfaction after having an experience of studying abroad, and that the same students (individuals) were surveyed both before and after a period of studying abroad.

This study has some limitations, being a small survey measuring stated behaviours by students responding to questions in a survey, rather than actual change of action (behaviour), that is using data collected from what the students expressed as their experiences. No comparison groups of nonmobile students were included. This implies that the presented conclusions apply mainly to the population studied. We declare no potential conflicts of interest with respect to the research covered in this article. However, it should be recognized that one of the authors was working at the International Office at Umeå University, Sweden, at the time the article was written.

\section{The questionnaire}

The survey used items from the Life Satisfaction Questionnaire (LiSat-11). LiSat-11 is a further development of LiSat-9 (Fugl-Meyer et al. 1991). It has a stable construction, and has been found to be valid for a general population. Levels of satisfaction are rated on a six-grade ordinal scale (from $1=$ very dissatisfied to $6=$ very satisfied), with higher scores indicating higher levels of life satisfaction. In accordance with previous studies and for purposes of comparison in using the LiSat-11 (Fugl-Meyer et al. 2002; Melin et al. 2003), the scale was dichotomized into either satisfied (5-6) or dissatisfied (1-4). The questionnaire comprised estimations of life satisfaction in general as well as with specific domains of one's life, such as one's academic situation, finances, leisure time, contact with friends and acquaintances, daily life, family life, partnership, somatic health, and psychological health. Since life satisfaction is an important indicator of how a person adjusts to new situations, this highlights the value of including aspects of it when studying international student mobility. The students were asked the question How satisfactory are these different aspects of your life? Indicate the number which best suits your situation for each of these statements.

This study used a standardized questionnaire, the Life Satisfaction Questionnaire (LiSat), which is a validated instrument that has been shown to have a robust and stable construct. In addition, the instrument was originally developed as a checklist for satisfaction of life for clinical and research purposes within rehabilitation medicine, and has been found to be valid for a general population.

\section{Statistics}

Data are presented as mean and standard deviation, where appropriate. Relative frequencies were calculated for the six response levels for the LiSat-11 domains before and after a period of studying abroad. All statistical analysis was performed using SPSS, version 21.0 for Windows. Non-parametric statistics were used to analyse the data. Differences in levels of life satisfaction (satisfied or dissatisfied) before and after six months of studies abroad were detected and analysed using McNemar's test. Multivariate binary logistic regression analyses were performed to analyse associations between gender, citizenship and length of studies and the domain life as a whole at follow-up.

The level of statistical significance was set at $p<0.05$.

\section{Results from the study}

Table 1 shows student characteristics for the first and second surveys; that is, what constitutes the panel. Most students were participating in credit mobility, studying for one or two terms as an exchange student. Most were citizens of an EU/EEA country (including Switzerland), and most were studying the Social Sciences, including Law and Business Administration. The panel consisted of approximately the same proportions of men and women. The non-respondents were also compared 
Table 1. A description of the participants in the first survey and the panel (i.e. the students who answered both surveys).

\begin{tabular}{l|c|c}
\hline & First survey n=296 (\%) & Panel $\mathbf{n = 1 1 6 ~ ( \% ) ~}$ \\
\hline Gender & $156(53)$ & $57(49)$ \\
Female & $139(47)$ & $59(51)$ \\
Male & $23.3 \pm 2.8$ & $24.5 \pm 2.8$ \\
\hline Mean age & $196(66)$ & $85(73)$ \\
\hline Citizenship & $95(32)$ & $30(26)$ \\
EU/EEA & $5(2)$ & $1(1)$ \\
Non-EU/EEA & & \\
Missing & $17(6)$ & $12(10)$ \\
\hline Field of studies & $162(55)$ & $52(45)$ \\
Humanities & $12(4)$ & $6(5)$ \\
Social Sciences (incl. Law \& Business) & $59(20)$ & $25(22)$ \\
Teacher Training & $22(7)$ & $4(3)$ \\
Natural Sciences and Technology & $9(3)$ & 0 \\
Medicine and Odontology & $2(1)$ & $6(5)$ \\
Healthcare & $13(4)$ & $95(82)$ \\
Arts and Fine Arts & & $21(18)$ \\
Missing & $244(83)$ & \\
\hline Length of studies & $51(17)$ & \\
Exchange students (1 or 2 terms) & & \\
Degree students (3 or more terms) & &
\end{tabular}

with the respondents in the follow-up survey regarding life satisfaction on LiSat-11 before the study period abroad (Fugl-Meyer et al. 2002; Melin et al. 2003). They reported a significantly lower level for the domain contact with friends $(p=0.013)$. In addition, an analysis of the non-respondents did not indicate any bias with respect to gender, age, or study programme.

The relative distribution of the inbound students among six levels of life satisfaction is shown in Table 2. The majority (61\%) were satisfied to very satisfied with life as a whole before studying abroad, and an even greater proportion (67\%) were satisfied to very satisfied after studying abroad. Half (50\%) of the 116 students were satisfied with their study situation before studying abroad, and this proportion had increased to $56 \%$ after the period of studying abroad. At follow-up, students had become more positive in reporting satisfaction with activities of daily living, finances, and somatic health. Before studying abroad, students reported being satisfied to very satisfied with their leisure activities, contact with friends, family life, partner relationship and psychological health, but after the experience abroad they reported less satisfaction in these domains.

In Table 3, differences in self-reported levels of life satisfaction on LiSat-11 (5-6) are compared before versus after having studied for a period abroad in inbound students and in subgroups of female and male students and, furthermore, European verssus non-European students. The whole group of inbound students reported significantly higher levels of satisfaction after the experience in the domains activities of daily living and somatic health. Non-significant higher levels were found for the domains life as a whole, study situation, and economy. The male students reported significantly higher satisfaction in the domains activities of daily living and somatic health at follow-up in comparison with before studying abroad. Although the female students also reported higher levels in these domains at follow-up, the results were non-significant. In addition, the results in Table 3 show that a low proportion of the nonEuropean students were satisfied with their economy both before and after studying abroad.

\section{Multivariate logistic analyses}

A multivariate logistic regression analysis was used to analyse associations between satisfaction with the domain life as a whole at follow-up after six months and the variables gender, citizenship, and length 
of studies. A statistically significant association was only found between shorter length of studies (1-2 terms) and life as a whole at follow-up (OR=2,750, Cl:1,213-6,232, $p=0.015$ ).

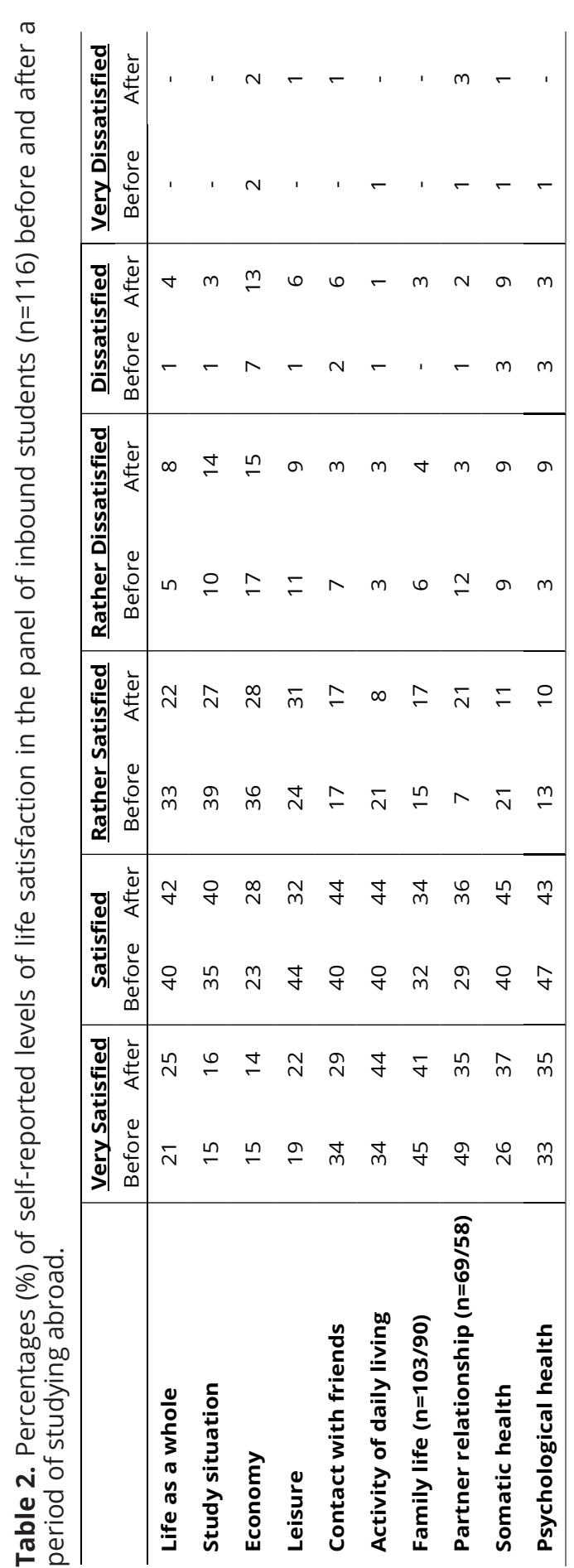

\section{Discussion}

International students arrive with a set of feelings and emotions, and depart with their own unique experience of life satisfaction. This study shows that the inbound students reported significantly higher satisfaction at follow-up after six months in the domains somatic health and activities of daily living. These findings could be related to lifestyle changes since sports, exercise, and outdoor activities are common at Umeå University. Physical activity has been shown to be related to satisfaction with life (Pedišić et al. 2015), participating in such activity during their stay may have affected the results for these students. This is also supported by an annual survey targeting international students, the International Student Barometer, in which international students top-ranked the sport facilities at the university (i-graduate 2015). Higher (nonsignificant) levels were found for the domains life as a whole, study situation and economy. In our study, we found a significant association with shorter study length and the overall life satisfaction domain life as a whole. One possible explanation for this could be that exchange students who have enrolled for one or two semesters are highly motivated to study abroad, while degree students aiming for a degree from a foreign $\mathrm{HEl}$ are under more pressure to succeed in their studies.

The findings of this study indicate that the inbound students reported a slightly higher level of satisfaction with their study situation after their experience of having studied abroad. This might be a consequence of their appreciating the academic, teaching, and learning experience. This experience covers a whole range of items, such as the academic content of courses, assessments and explanation of marking criteria, learning spaces, class size, the English proficiency of support staff, the learning technology (PCs, networking, etc.), and the physical library facilities.

Some previous studies have reported higher life satisfaction among female students regarding social support among peers, and significantly greater emotional loneliness in male than female students (Salimi 2011; Yalçun 2011). These findings were not confirmed in our study; the female students reported slightly lower levels of life satisfaction as regards contact with friends and psychological health at follow-up, in contrast to the male students, who 
Table 3. Differences in self-reported levels of life satisfaction (in percentages of very satisfied and satisfied, dichotomized as 'satisfied' in accordance with the developer of LiSat-11) for inbound students, inbound women, inbound men, European students, and non-European students before vs. after studying abroad $(* * p<0.01, * p<0.05)$.

\begin{tabular}{l|c|c|c|c|c}
\hline & $\begin{array}{c}\text { Inbound students } \\
(\mathrm{n}=116)\end{array}$ & $\begin{array}{c}\text { Inbound women } \\
(\mathrm{n}=57)\end{array}$ & $\begin{array}{c}\text { Inbound men } \\
(\mathrm{n}=59)\end{array}$ & $\begin{array}{c}\text { EU/EEA } \\
(\mathrm{n}=85) \\
(\%)\end{array}$ & $\begin{array}{c}\text { Non-EU/EEA } \\
(\mathrm{n}=30) \\
(\%)\end{array}$ \\
\hline Life as a whole & $61 / 66$ & $66 / 68$ & $56 / 66$ & $63 / 68$ & $53 / 60$ \\
\hline Study situation & $51 / 56$ & $46 / 47$ & $56 / 66$ & $49 / 56$ & $53 / 53$ \\
\hline Economy & $38 / 42$ & $37 / 47$ & $39 / 36$ & $46 / 52$ & $17 / 13$ \\
\hline Leisure & $63 / 53$ & $70 / 58$ & $57 / 48$ & $68 / 59$ & $48 / 37$ \\
\hline Contact with friends & $74 / 73$ & $79 / 74$ & $69 / 73$ & $78 / 77$ & $67 / 63$ \\
\hline Activity of daily living & $75 / 88 * *$ & $75 / 84$ & $75 / 91 *$ & $75 / 89 *$ & $73 / 83$ \\
\hline Family life & $\begin{array}{c}77 / 74 \\
(\mathrm{n}=103 / 90)\end{array}$ & $\begin{array}{c}84 / 72 \\
(\mathrm{n}=49 / 48)\end{array}$ & $\begin{array}{c}78 / 73 \\
(\mathrm{n}=55 / 42)\end{array}$ & $\begin{array}{c}81 / 79 \\
(\mathrm{n}=78 / 70)\end{array}$ & $\begin{array}{c}72 / 65 \\
(\mathrm{n}=25 / 20)\end{array}$ \\
\hline Partner relationship & $\begin{array}{c}78 / 71 \\
(\mathrm{n}=69 / 58)\end{array}$ & $87 / 74$ & $80 / 71$ & $72 / 69$ \\
$(\mathrm{n}=36 / 27)$ & $67 / 81$ & $66 / 83 *$ & $67 / 83^{* *}$ & $63 / 77$ \\
\hline Somatic health & $66 / 82 * *$ & $82 / 75$ & $78 / 83$ & $81 / 80$ & $77 / 73$ \\
\hline Psychological health & $80 / 79$ & & & \\
\hline
\end{tabular}

reported a higher level of satisfaction with friends after a period of studying abroad. Several studies indicate that financial concerns have a significant impact on life satisfaction (e.g. Sam 2001; Paolini et al. 2006) regarding, for instance, cost of living, textbooks, accommodations, and leisure. In the present study, it is worth noting that students' satisfaction with their economy was the only domain rated below 50\%. In addition, the non-European students rated satisfaction with their economy lower than 20\%. Exchange students participating in the Erasmus programme receive a stipend that aims to make it easier for all students, including those with the least resources; this in contrast to many nonEuropean students, for whom earning money while studying is a major concern.

The findings indicate that studying abroad has an impact on students' reported life satisfaction, which is to some extent in line with some previous studies (cf. Burns 1991; Sandhu 1994; Snow Andrade 2006; Sawir et al. 2008; Russel et al. 2010; Bhandari 2012). This might suggest that life satisfaction can be intertwined with and related to intrapersonal factors and how the students interact with peers when studying abroad (Sandhu 1994). The experience of being an international student covers different domains of life satisfaction and how the students appreciate the study situation, academic teaching and learning experience, leading towards issues of lifestyle aspirations. Life satisfaction is one way of evaluating students' contentment with their life after a sojourn abroad. Life satisfaction highlights the degree to which the students are able to attain their objectives; it should also be viewed as interrelated with lifestyle among youth. Lifestyle mobility indicates a search for a better life somewhere else, such as a warmer climate, cosmopolitan experiences from big cities, and some studies have observed back-and-forth waves of circular mobility as an expression of defining characteristics of contemporary life (cf. Cresswell 2006; Sheller \& Urry 2006; King 2017).

Lifestyle mobility is a project for pursuing self-realization, and suggests movements mostly of free will and related to individuals' life values (cf. Benson \& O'Reilly 2009; Duncan et al. 2013; Åkerlund 2013; Cohen et al. 2015). These studies conceptualize individuals' behaviour patterns in activities, attitudes, interests, opinions, and values pertinent to mobility. It often also reflects people's self-image - the way they see themselves and believe they are seen by others (cf. Urry 2002; Jonsson 2003; Benson \& O'Reilly 2009; Kennedy 2010; Åkerlund 2013). Cohen, Duncan and Thulemark (2015) argue that, for some, being on the move has become a way of life and something that continues throughout the life course. King (2017) argues that youth mobility in Europe is not only dictated by work, income, career and so forth, but also shaped by a search for a better life. 
Some geographers have studied aspects such as diaspora and affinity in relation to what is conceptualized as domestic and foreign (Ho 2017; Ho \& McConnell 2017). It seems evident that some international students struggle with their new identities, relationships, networks, rights, and responsibilities. Some have an affinity with the international community and others are experiencing feelings of between two worlds affecting how satisfied they are with their life studying abroad. For international students, it is important to be connected with peers and the overall student community, as well as with family and friends at home (e.g. Burns 1991; Sandhu 1994; Sawir et al. 2008; Russel et al. 2010; Bhandari 2012). This was also indicated in the present study by the findings of somewhat lower levels of satisfaction with family life and partner relationship after the study period. The development of information and communication technologies has opened up new possibilities, and the world has become more accessible. Thus, social media can help students stay connected with their family and friends, creating a sense of home away from home (Gomes et al. 2014). Even if technical facilities and devices continue to improve the situation for all international students, problems with adaptation need to be addressed.

Studies have shown that, when in unfamiliar surroundings, foreign students fail to actively seek help (cf. Russel et al. 2010; Morris-Lange \& Brands 2015). Therefore, universities need to be aware of at-risk students and provide them adequate support. At Umeå University, a Buddy Programme offers international students social support aimed at integrating them with the rest of the student community. The way students are connected is crucial for their wellbeing and for helping them avoid feelings of loneliness and isolation. The roles of academic and social integration, as well as academic and social adjustment, are significant regarding retention and persistence in higher education. Furthermore, the issue of being connected - maintaining relationships with family and peers - has been shown to be important for life satisfaction (Russell et al. 2010). Those who are 'positively connected' indicate higher levels of life satisfaction and, furthermore, those who are 'positively connected' mix with peers from the whole student population and participate in activities outside the community of students from where they originated (Ibid.).

Most of the international students participating in this study were exchange students, and are thus doing this voluntarily and highly motivated (Nilsson 2015). As Teichler (2017) pointed out, the vast majority of exchange students do not expect a higher level of teaching or substance of knowledge taught. They have other aims, such as living in another country, exploring a new culture, or personal development (Ibid.). Still, the experience made the students change their stance on certain items after a sojourn abroad in comparison to what they had expected. In comparison with a Swedish reference sample of 2,533 individuals aged 18-64 (Fugl-Meyer et al. 2002), the participants in the present study scored higher estimates in the domains contact with friends and somatic health. Although the reference sample includes different ages and not only students, our results may suggest that internationally mobile students are different from non-mobile comparison groups, and form a selection of the population studying abroad. Different aspects of inequality require more studies (Bilecen \& van Mol 2017), and this article adds to a discussion on the relationship between international student mobility and inequalities, by using panel of inbound students. Some students lack the means to travel, and Cresswell (2006) has coined the expression 'mobility poor' to conceptualize a power relation embedded in international student mobility. Moreover, in a previous study including the Umeå University inbound students, they reported positive perceptions of working abroad in the future (Nilsson 2015), the positive ratings of several of the life satisfaction domains at follow up may have contributed to these attitudes.

\section{Conclusion}

The transition from one's home country to a university abroad is a significant life event for the individuals, and students studying abroad may experience numerous challenging life events (cf. Bochner et al. 1977; Black \& Mendenhall 1990; Fitria 2013); thus, it is important to understand the adjustment to a new country. Some scholars have focused on the adjustment among international students to a new study system and a new country. Even though internationally mobile students are a select group of students with different backgrounds and preparations for studying abroad, it is also likely that they differ from non-mobile students (Waibel et al. 2017). This study showed that 
international student mobility may have an effect on certain aspects of life satisfaction. In general, inbound students were satisfied with different domains of life satisfaction, both before and after a period of studying abroad. It was shown that the domains somatic health and activities of daily living were significantly higher at follow-up. However, more follow-up studies are needed with regard to the life satisfaction of international students as well as individual students' assessments and future lifestyle aspirations, moving away from a static perception of international mobility.

\section{References}

Beech, S. E. (2014) International student mobility: the role of social networks. Social \& Cultural Geography 16(3) 332-350. https://doi.org/10.1080/14649365.2014.983961

Bell, M. \& Ward, G. (2000) Comparing temporary mobility with permanent migration. Tourism Geographies 2(1) 87-107. https://doi.org/10.1080/146166800363466

Benson, M. \& O'Reilly, K. (2009) Migration and search for a better way of life: a critical exploration of lifestyle migration. The Sociological Review 57(4) 608-625. https://doi. org/10.1111/j.1467-954X.2009.01864.X

Bhagwati, J. (1976) "The brain drain, international integration of markets for professionals and unemployment: a theoretical analysis". Journal of Development Economics 1(1) 19-42. https://doi. org/10.1016/0304-3878(74)90020-0

Bhandari, P. (2012) Stress and health related quality of life of Nepalese students studying in South Korea: a cross sectional study. Health and Quality of Life Outcomes 10(26). https://doi. org/10.1186/1477-7525-10-26

Bilecen, B. \& van Mol, C. (2017) Introduction: international academic mobility and inequalities. Journal of Ethnic and Migration Studies 43(8) 1241-1255. https://doi.org/10.1080/136918 3X.2017.1300225

Black, J. S. \& Mendenhall, M. (1990) Cross-cultural training effectiveness: a review and a theoretical framework for future research. Academy of Management Review 15(1) 113-136. https://doi. org/10.5465/amr.1990.11591834

Bochner, S., McLeod, B. M. \& Lin, A. (1977) Friendship patterns of overseas students. Journal of Social Psychology 110(2) 265-272. https://doi.org/10.1080/00224545.1980.9924253

Bogren, H. (2008) Flytta eller stanna? Betydelsen av plats och platsförankring för den kvalificerade arbetskraftens internationella migration. Doctoral thesis in the Department of Social and Economic Geography. Lund University, Lund. (in Swedish)

Boyle, P., Halfacree, K. \& Robinson, V. (1998) Exploring Contemporary Migration. Addison Wesley Longman, New York.

Bracht, O., Engel C., Janson, K., Over, A., Schomburg, H. \& Teichler, U. (2006) The Professional Value of ERASMUS Mobility. Final Report of the VALERA project. International Centre for Higher Education Research (INCHER-Kassel), University of Kassel, Kassel.

Brooks, R. \& Waters, J. (2010) Social networks and educational mobility: the experience of UK students. Globalization, Societies and Education 8(1) 143-157. https://doi.org/10.1080/14767720903574132

Burns, R. B. (1991) Study and stress among first year overseas students in an Australian University. Higher Education Research \& Development 10(1) 61-77. https://doi.org/10.1080/0729436910100106

Börjesson, M. (2005) Transnationella utbildningsstrategier vid svenska lärosäten och bland svenska studenter i Paris och New York. Doctoral thesis in the Department of Education. Uppsala University, Uppsala. https://www.google.com/url?sa=t\& $r c t=j \& q=\& e s r c=s \&$ source=web\& $c d=1 \& v e d=2 a h U K E$ wij d7y4rPgAhUJWZoKHeJdA14QFjAAegQIBRAC\&url=http\%3A\%2F\%2Fwww.skeptron.uu. se\%2Fbroady\%2Fsec\%2Fsec-37.pdf\&usg=AOvVaw2wlbBWVLBtdKgzEB02BzDb

Börjesson, M. (2017) The global space of international students in 2010. Journal of Ethnic and Migration Studies 43(8) 1256-1275. https://doi.org/10.1080/1369183X.2017.1300228

Chow, H. P. H. (2005) Life satisfaction among university students in a Canadian prairie city: a multivariate analysis. Social Indicators Research 70(2) 139-150. https://doi.org/10.1007/s11205004-7526-0

Cohen, S. A., Duncan, T. \& Thulemark, M. (2015) Lifestyle mobilities: the crossroads of travel, leisure and migration. Mobilities 10(1) 155-172. https://doi.org/10.1080/17450101.2013.826481

Cresswell, T. (2006) On the move. Mobility in the Modern Western World. Routledge, New York.

Deakin, H. (2014) The drivers to Erasmus work placement mobility for UK students. Children's Geographies 12(1) 25-39. https://doi.org/10.1080/14733285.2013.851063 
Duncan, T., Scott, D. S. \& Bauman, T. (2013) The mobility of hospitality work: an exploration of issues and debates. Annals of Tourism Research 41 1-19. https://doi.org/10.1016/j.annals.2012.10.004

European Commission (2014). Erasmus: facts, figures \& trends: the European Union support for student and staff exchanges and university cooperation in 2012-2013. Publications Office of the European Union, Luxembourg.

Findlay, A. M., King, R., Geddes, A., Smith, F.M., Geddes, A. \& Skeldon, R. (2012) World class? An investigation of globalization, difference and international student mobility. Transactions of the Institute of British Geographers 37(1) 118-131. https://doi.org/10.1111/j.1475-5661.2011.00454.x

Findlay, A. M., King, R., Stam, A. \& Ruiz-Gelices, E. (2006) Ever reluctant Europeans: the changing geographies of UK students studying and working abroad. European Urban and Regional Studies 13(4) 291-318. https://doi.org/10.1177/0969776406065429

Fitria, D. (2013) Life satisfaction and social anxiety among international university students. Master thesis from Faculty of Education and Human Development, Sultan Idris Education University, Perak, Malaysia.

Forbes-Mewett, H. \& Sawyer, A-M. (2016) International students and mental health. Journal of International Students 6(3) 661-677.

Fugl-Meyer, A. R., Bränholm, I-B. \& Fugl-Meyer, K. S. (1991) Happiness and domain specific life satisfaction in adult northern Swedes. Clinical Rehabilitation 5(1) 25-33. https://doi. org/10.1177/026921559100500105

Fugl-Meyer, A. R., Melin, R. \& Fugl-Meyer, K. S. (2002) Life satisfaction in 18- to 64-year-old Swedes: in relation to gender, age, partner and immigrant status. Journal of Rehabilitation Medicine 34(5) 239-246. https://doi.org/10.1080/165019702760279242

Gomes, C., Berry, M., Alzougool, B. \& Chang, S. (2014) Home away from home: international students and their identity-based social networks in Australia. Journal of International Students 4(1) 2-15.

Hall, C. M. \& Page, S. J. (2009) Progress in tourism management: from the geography of tourism to geographies of tourism - a review. Tourism Management 30(1) 3-16. https://doi.org/10.1016/j. tourman.2008.05.014

Hall, C. M. (2005a) Space-time accessibility and the tourist area cycle of evolution: the role of geographies of spatial interaction and mobility in contributing to an improved understanding of tourism. In Butler, R. (ed.) The Tourism Life Cycle: Conceptual and Theoretical Issues, 83-100. Channelview Publications, Clevedon.

Hall, C. M. (2005b) Tourism. Rethinking the Social Science of Mobility. Prentice Hall, Harlow, Essex.

Hall, C. M., Williams, A. M. \& Lew, A. A. (2014) Tourism conceptualizations, disciplinarity, institutions, and issues. In Lew, A., Hall, C. M. \& Williams, A. M. (eds.) The Wiley Blackwell Companion to Tourism, 3-24. Wiley, Chichester.

Hauschildt, K., Gwosć, C., Netz, N. \& Mishra, S. (2015) Social and Economic Conditions of Student Life in Europe. Synopsis of Indicators. EUROSTUDENT V, 2012-2015. W. Bertelsmann Verlag.

Helliwell, J. K, Huang, H. \& Wang, S. (2017) Social foundations of world happiness. In Helliwell, J., Layard, R. \& Sachs, J. (eds.) World Happiness, 8-47. UN SDSN, New York.

Ho, E. L-E. \& McConnell, F. (2017) Conceptualizing 'diaspora diplomacy': territory and populations betwixt. the domestic and foreign. Progress in Human Gepgraphy 1-21.

Ho, E. L-E. (2017) Mobilising affinity ties: Kachin internal displacement and the geographies of humanitarianism at the China-Myanmar border. Transactions of the Institute of British Geographers 42 84-97. https://doi.org/10.1111/tran.12148

i-graduate (2015) International Student Barometer. Umeå University results when participating in the survey. Umeå, Sweden.

Jacobsson, L. \& Lexell, J. (2013) Life satisfaction 6-15 years after a traumatic brain injury. Journal of Rehabilitation Medicine 45(10) 1010-1015. https://doi.org/10.2340/16501977-1204

Janelle, D. G. \& Hodge, D. (2000) Information, Place and Cyberspace: Issues in Accessibility. SpringerVerlag, Berlin. https://doi.org/10.1007/978-3-662-04027-0

Jonsson, G. (2003) Rotad, rotlös, rastlös [Rooted, rootless and restless young]. GERUM Kulturgeografi 2003(3) Doctoral thesis in the Department of Geography. Umeå University, Umeå. (in Swedish).

Kennedy, P. (2010) Mobility, flexible lifestyles and cosmopolitanism: EU postgraduates in Manchester. Journal of Ethnic and Migration Studies 36(3) 465-482. https://doi.org/10.1080/13691830903426838

King, R. \& Ruiz-Gelices, E. (2003) International student migration and the European 'year abroad': effects on European identity and subsequent migration behavior. Population, Space and Place 9(3) 229-252. https://doi.org/10.1002/ijpg.280 
King, R. (2017) Theorising new European youth mobilities. Population Space and Place 24(1) 1-12. https://doi.org/10.1002/psp.2117

King, R., Findlay, A. \& Ahrens, J. (2010) International Student Mobility Literature Review. Higher Education Funding Council for England (HEFCE), Bristol.

Knight, J. (2012) Student mobility and internationalization: trends and tribulations. Research in Comparative and International Education 7(1) 20-33. https://doi.org/10.2304/rcie.2012.7.1.20

Kondakci, Y. (2011) Student mobility reviewed: attraction and satisfaction of international students in Turkey. Higher Education 62(5) 573-592. https://doi.org/10.1007/s10734-011-9406-2

Lin, J. G. \& Yin, J. K. (1997) Asian international students adjustment: issues and program suggestions. College Student Journal 31(4) 473-480.

Lysgård, H. K. \& Rye, S. A. (2017) Between striated and smooth space: exploring the topology of transnational student mobility. Environment and planning A 49(9) 2116-2134. https://doi. org/10.1177/0308518X17711945

Melin, R. (2003) On life satisfaction and vocational rehabilitation outcome in Sweden. Doctoral thesis in Faculty of Medicine. Uppsala University, Uppsala. http://www.diva-portal.org/smash/get/ diva2:162949/FULLTEXT01.pdf

Melin, R., Fugl-Meyer, K. S. \& Fugl-Meyer, A. R. (2003) Life satisfaction in 18- to 64-year-old Swedes: in relation to education, employment situation, health and physical activity. Journal of Rehabilitation Medicine 35 84-90. https://doi.org/10.1080/16501970306119

Morris-Lange, S. \& Brands, F. (2015) Train and Retain: Career Support for International Students in Canada, Germany, the Netherlands and Sweden. SVR's Research Unit: Study 2015-2. Berlin, Germany.

Murphy-Lejeune, E. (2002) Student Mobility and Narrative in Europe. The New Strangers. Routledge, London.

Nilsson, P. A. (2015) Expectations and experiences of inbound students: perspectives from Sweden. Journal of International students 5(2) 161-174.

OECD (2014) Education at a Glance 2014: OECD Indicators. OECD Publishing, Paris.

Olutayo, A. O. (2017) Money drain, the diaspora remittance issue and higher education in Nigeria. Journal of international Mobility 1(5) 13-42. https://doi.org/10.3917/jim.005.0013

Paige, M. R., Fry, G. W., Stallman, M. E., Josic, J. \& Jon J-E. (2009) Study abroad for global engagement: the long-term impact of mobility experiences. Intercultural Education 20(1-2) S29-S44. https:// doi.org/10.1080/14675980903370847

Paolini, L., Yanez, A. P. \& Kelly, W. (2006) An examination of worry and life satisfaction among college students. Individual Differences Research 4(4) 331-339.

Pavot, W., Diener, E., Colvin, C. R. \& Sandvik, E. (1991) Further validation of the satisfaction with life scale: evidence for the cross-method convergence of well-being measures. Journal of Personality Assessment 57(1) 149-161. https://doi.org/10.1207/s15327752jpa5701 17

Pedišić, Z., Greblo, Z., Phongsavan, P., Milton, K. \& Bauman, A. E. (2015) Are total, intensity- and domain-specific physical activity levels associated with life satisfaction among university students? PLOS ONE 10(2) e0118137. https://doi.org/10.1371/journal.pone.0118137

Perkins, R. \& Neumayer, E. (2014) Geographies of educational mobilities: exploring the uneven flows of international students. The Geographical Journal 180(3) 246-259. https://doi.org/10.1111/ geoj.12045

Prazeres, L. (2018) Unpacking distinction within mobility: social prestige and international students. Population, Space and Place. https://doi.org/10.1002/psp.2190

Rienties, B. \& Tempelaar, D. (2013) The role of cultural dimensions of international and Dutch students on academic and social integration and academic performance in the Netherlands. International Journal of Intercultural Relations 37(2) 188-201. https://doi.org/10.1016/j. ijintrel.2012.11.004

Rode, J. C., Arthaud-Day, M. L., Mooney, C. H., Near, J. P., Baldwin, T. T., Bommer, W. H., \& Rubin, R. S. (2005) Life satisfaction and student performance. Academy of Management Journal of Learning and Education 4(4) 421-433. https://doi.org/10.5465/amle.2005.19086784

Russell, J., Rosenthal, D. \& Thomson, G. (2010) The international student experience: three styles of adaption. Higher Education 60(2) 235-249. https://doi.org/10.1007/s10734-009-9297-7

Salimi, A. (2011) Social-emotional loneliness and life satisfaction. Procedia - Social and Behavioral Sciences 29 292-295. https://doi.org/10.1016/i.sbspro.2011.11.241

Salinas-Jiménez, A. \& Salinas- Jiménez, J. (2011) Education as a positional good: a life satisfaction approach. Social Indicators Research 103(3) 409-426. https://doi.org/10.1007/s11205-010-9709-1 
Sam, D. L. (2001) Satisfaction with life among international students: an exploratory study. Social Indicators Research 53(3) 315-337. https://doi.org/10.1023/A:1007108614571

Sandhu, D. S. (1994) An examination of the psychological needs of the international students: implications for counselling and psychotherapy. International Journal for the Advancement of Counselling 17(4) 229-239. https://doi.org/10.1007/BF01407739

Sawir, E., Marginson, S., Deumert, A., Nyland, C. \& Ramia, G. (2008) Loneliness and international students: an Australian study. Journal of Studies in International Education 12(2) 148-180. https:// doi.org/10.1177/1028315307299699

Sheller, M. \& Urry, J. (2006) The new mobilities paradigm. Environment and Planning A 38(2) 207-226. https://doi.org/10.1068/a37268

Shin, D. \& Johnson, D. (1978) Avowed happiness as an overall assessment of quality of life. Social Indicators Research 5(1-4) 475-492. https://doi.org/10.1007/BF00352944

Snow Andrade, M. (2006) International students in English-speaking universities. Journal of Research in International Education 5(2) 131-154. https://doi.org/10.1177/1475240906065589

SOU (2018) En strategisk agenda för internationalisering. Delbetänkande av utredningen om ökad internationalisering av universitet och högskolor. Statens offentliga utredningar 2018(3). Statens Offentliga Utredningar, Stockholm. (in Swedish)

Souto-Otero, M., Huisman, J., Beerkens, M., de Wit, H. \& Vujić, S. (2013) Barriers to international student mobility: evidence from the Erasmus program. Educational Research 41(2) 70-77. https:// doi.org/10.3102/0013189X12466696

Teichler, U. (2002) Erasmus in the Socrates Programme. Findings of an Evaluation Study. Bonn, Lemmens.

Teichler, U. (2017) Internationalisation trends in higher education and the changing role of international student mobility. Journal of international Mobility 1(5) 177-216. https://doi. org/10.3917/jim.005.0179

UK $\ddot{A}$ [Swedish Higher Education Authority] (2016) Arsrapport [Annual Report]. 2016:10. Universitetskanslersämbetet, Stockholm (in Swedish).

UNESCO (2014) Global flew of tertiary level students. Updated every year. <http://uis.unesco.org/en/ uis-student-flow>

Urry, J. (2000) Sociology Beyond Societies: Mobilities for the Twenty-First Century. Routledge, London.

Urry, J. (2002) Mobility and proximity. Sociology 36(2) 255-274. https://doi. org/10.1177/0038038502036002002

Varghese, N. V. (2008) Globalization of higher education and cross-border student mobility. Research papers IIEP. International Institute for Educational Planning. Paris.

Waibel, S., Rüger, H., Ette, A. \& Sauer, L. (2017) Career consequences of transnational educational mobility: a systematic literature review. Educational Research Review 20 81-98. https://doi. org/10.1016/j.edurev.2016.12.001

Wells, A. (2014) International student mobility: approaches, challenges and suggestions for further research. Procedia - Social and Behavioral Sciences 143 19-24. https://doi.org/10.1016/j. sbspro.2014.07.350

Wiers-Jenssen, J. (2008) Does higher education attained abroad lead to international jobs? Journal of Studies in International Education 12(2) 101-130. https://doi.org/10.1177/1028315307307656

Yalçun, I. (2011) Social support and optimism as predictors of life satisfaction of college students. International Journal for the Advancement of Counselling 33(2) 79-87. https://doi.org/10.1007/ s10447-011-9113-9

Åkerlund, U. (2013) The Best of Both Worlds. Aspirations, Drivers and Practices of Swedish Lifestyle Movers in Malta. Doctoral dissertation in Geography at the Department of Geography and Economic History. GERUM 2013:2. Umeå University, Sweden. http://www.diva-portal.org/smash/ get/diva2:664246/FULLTEXT01.pdf

Åkerlund, U. (2017) Strategic lifestyle management in later life: Swedish lifestyle movers in Malta seeking the 'best of both worlds'. Population, Space and Place 23(1) e1964. https://doi.org/10.1002/ psp.1964 